\title{
Determinan Pengangguran Lulusan SMA di Provinsi Sumatera Utara Tahun 2019
}

\author{
(Determinants of Unemployment for High School Graduates in North Sumatra Province 2019) \\ Viki Tria Zianrini ${ }^{*}$, Efri Diah Utami² \\ ${ }^{1,2}$ Politeknik Statistika STIS \\ Jalan Otto Iskandardinata No. 64C 14, Rt.1/Rw.4, Bidara Cina, Jatinegara, Jakarta Timur 13330 \\ E-mail: 111810644@stis.ac.id
}

\begin{abstract}
ABSTRAK
Pengangguran merupakan salah satu masalah yang masih banyak terjadi di negara berkembang. Di Indonesia, pengangguran didominasi oleh angkatan kerja yang berpendidikan tinggi atau disebut pengangguran terdidik. Jumlah pengangguran terdidik tahun 2016 hingga tahun 2019 cenderung mengalami kenaikan. Berdasarkan data BPS tahun 2019, penduduk berumur 15 tahun ke atas yang termasuk pengangguran terbuka menurut pendidikan tertinggi yang ditamatkan terbanyak adalah mereka yang berpendidikan terakhir SMA yaitu mencapai 1.994.836 jiwa. Provinsi Sumatera Utara merupakan provinsi yang menempati posisi pertama dengan jumlah pengangguran lulusan SMA terbanyak dibandingkan dengan provinsi lainnya di Pulau Sumatera. Meningkatnya pengangguran lulusan SMA akan menimbulkan dampak ekonomis terhadap daerah di sekitarnya. Dengan menggunakan data sekunder hasil Survei Angkatan Kerja Nasional Agustus 2019, penelitian ini bertujuan untuk mengetahui variabel-variabel yang memengaruhi status menganggur lulusan SMA di Sumatera Utara tahun 2019 menggunakan analisis regresi logistik biner. Hasil penelitian menunjukkan bahwa variabel yang signifikan memengaruhi status menganggur lulusan SMA adalah umur, wilayah tempat tinggal, status perkawinan, dan status dalam rumah tangga. Untuk lulusan SMA yang berumur muda, tinggal di wilayah perkotaan, berstatus bukan sebagai kepala rumah tangga, dan belum kawin memiliki kecenderungan yang lebih besar untuk menganggur.
\end{abstract}

Kata kunci: lulusan SMA, pengangguran terdidik, regresi logistik biner

\begin{abstract}
Unemployment is one of the most common problems in developing countries. In Indonesia, unemployment is dominated by a highly educated workforce or so-called educated unemployment. The number of educated unemployed from 2016 to 2019 tends to increase. Based on BPS data in 2019, the population aged 15 years and over who are included in open unemployment according to the highest education completed are those with the latest high school education, reaching 1,994,836 people. North Sumatra Province is the province that occupies the first position with the highest number of unemployed high school graduates compared to other provinces on the island of Sumatra. The increase in unemployment for high school graduates will have an economic impact on the surrounding area. By using secondary data from the August 2019 National Labor Force Survey, this study aims to determine the variables that affect the unemployment status of high school graduates in North Sumatra in 2019 using binary logistic regression analysis. The results showed that the variables that significantly influenced the unemployment status of high school graduates were age, area of residence, marital status, and status in the household. For high school graduates who are young, live in urban areas, are not the head of the household, and are not married have a greater tendency to be unemployed.
\end{abstract}

Keywords: high school graduates, educated unemployment, binary logistic regression

\section{PENDAHULUAN}

Indonesia diperkirakan akan mengalami bonus demografi pada tahun 2020-2030 (Umar, 2017). Pada periode tersebut jumlah penduduk usia produktif (15-54 tahun) lebih banyak dibandingkan dengan jumlah penduduk usia tidak produktif (0-14 tahun dan 65 tahun ke atas). Bonus demografi dapat dilihat dari parameter rasio ketergantungannya yang diprediksi akan mencapai titik terendah yaitu 44,2 persen pada tahun 2025 . Hal ini berarti dalam setiap 100 penduduk usia produktif akan menanggung sekitar 44 penduduk tidak produktif. Peningkatan penduduk usia produktif ini harus sejalan dengan bertambahnya ketersediaan lapangan pekerjaan. Jika angkatan kerja semakin bertambah banyak sedangkan lapangan pekerjaan tidak mencukupi, maka akan meningkatkan jumlah pengangguran yang ada. Selain ketersediaan lapangan pekerjaan yang tidak mencukupi, penyebab lain dari pengangguran adalah tidak adanya kemampuan dan buruknya kualitas sumber daya manusia, sehingga perusahaan-perusahaan yang ada tidak mampu menyerap angkatan kerja tersebut. 
Saat ini pengangguran di Indonesia masih didominasi oleh angkatan kerja yang berpendidikan tinggi atau disebut pengangguran terdidik. Pengangguran terdidik merupakan angkatan kerja yang berpendidikan minimal SMA sederajat yang tidak bekerja (Tobing, 2007). Berdasarkan hasil Survei Angkatan Kerja Nasional (Sakernas) Agustus 2019 oleh Badan Pusat Statistik, penduduk berumur 15 tahun ke atas yang termasuk pengangguran terbuka menurut pendidikan tertinggi yang ditamatkan terbanyak adalah mereka yang berpendidikan terakhir SMA yaitu mencapai 1.994.836 jiwa dan diikuti oleh tamatan SMK sebesar 1.727.167 jiwa. Tingginya jumlah lulusan SMA yang menganggur disebabkan karena siswa SMA yang tidak melanjutkan pendidikannya ke jenjang yang lebih tinggi dihadapkan dengan persaingan tidak seimbang dalam mendapatkan pekerjaan dengan lulusan SMK yang mana dari segi keterampilan dan pengalaman lebih memadai (Alam, 2016).

Pengangguran terdidik khususnya yang berpendidikan terakhir SMA masih menjadi masalah yang banyak terjadi di provinsi-provinsi Indonesia, termasuk Sumatera Utara. Dengan jumlah 130.103 pengangguran lulusan SMA, Sumatera Utara menjadi provinsi dengan jumlah pengangguran terdidik lulusan SMA tertinggi nomor lima di Indonesia pada tahun 2019 berdasarkan data Badan Pusat Statistik. Di antara provinsi yang ada di Pulau Sumatera, Sumatera Utara menempati urutan pertama dengan jumlah pengangguran terdidik lulusan SMA terbanyak.

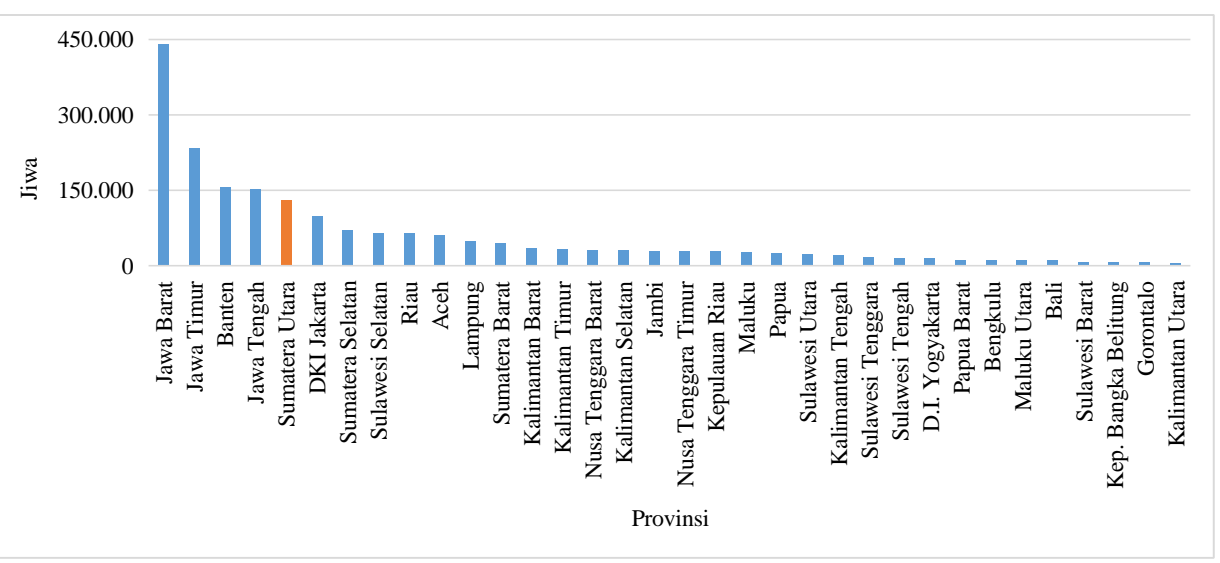

Sumber: Badan Pusat Statistik

Gambar 1. Jumlah pengangguran terdidik lulusan SMA di Indonesia tahun 2019 (Jiwa)

Dilihat dari jenjang pendidikan, pada tahun 2019 lulusan SMA yang menganggur di Sumatera Utara mendominasi di antara jenjang pendidikan yang lain. Gambar 2 memperlihatkan bahwa terjadi peningkatan pada pengangguran lulusan SMA yang mana pada tahun 2018 sebanyak 129.119 jiwa dan naik menjadi 130.103 jiwa pada tahun 2019. Selain lulusan SMA, pada jenjang pendidikan lulusan SMK juga terindikasi memiliki jumlah pengangguran yang tinggi, namun terjadi penurunan yang mana pada tahun 2018 tercatat sebanyak 94.465 pengangguran dan pada tahun 2019 turun menjadi 90.298 pengangguran. Sedangkan untuk jenjang pendidikan yang lain yaitu SD, SMP, Diploma I/II/III, dan universitas memiliki jumlah pengangguran yang rendah dan cenderung mengalami penurunan pada tahun 2018 hingga 2019.

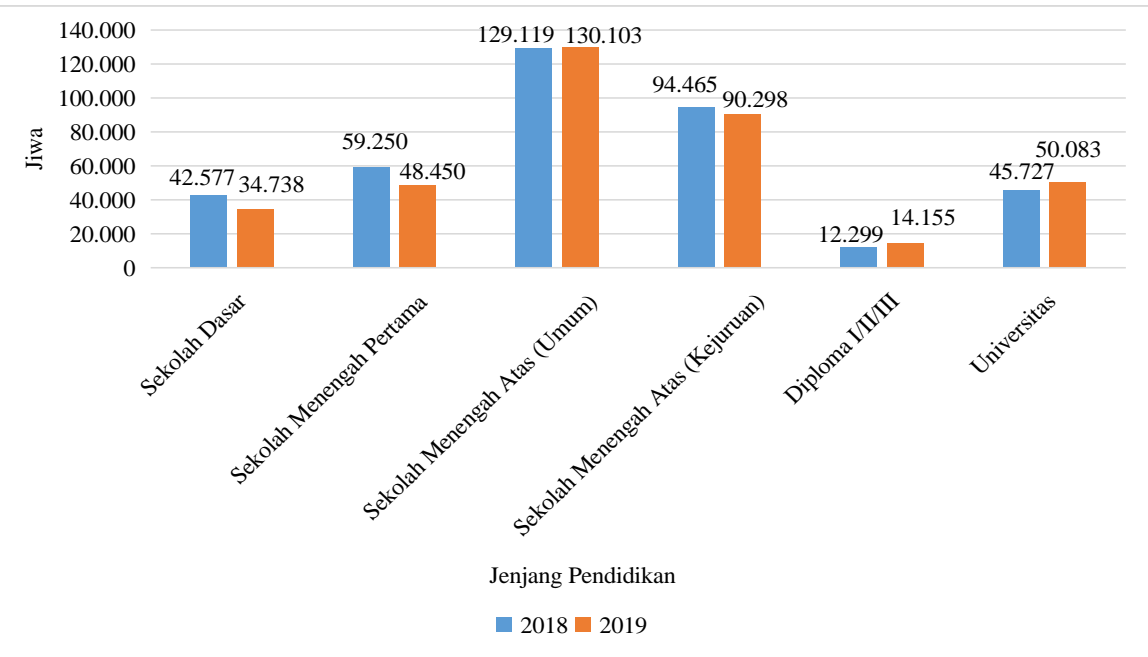

Sumber: Badan Pusat Statistik

Gambar 2. Jumlah pengangguran menurut jenjang pendidikan di Sumatera Utara tahun 2018-2019 (Jiwa) 
Kurangnya pelatihan dan pengalaman kerja yang dimiliki lulusan SMA diduga menjadi penyebab sulitnya mendapatkan pekerjaan. Hal tersebut dikarenakan tidak adanya kecocokan pada kurikulum SMA dengan kebutuhan dunia kerja. Pemerintah telah mengupayakan berbagai cara agar pengangguran terdidik lulusan SMA berkurang, salah satunya dengan menciptakan target memperbanyak jumlah sekolah dan jumlah siswa SMK di Indonesia. Namun hingga 2019, Provinsi Sumatera Utara belum mencapai target tersebut. Berdasarkan data Kementerian Pendidikan dan Kebudayaan, Sumatera Utara menempati posisi pertama dengan jumlah siswa dan sekolah SMA terbanyak jika dibandingkan dengan SMK. Dengan bertambahnya jumlah sekolah dan siswa SMA di Provinsi Sumatera Utara dari tahun ke tahun, jumlah lulusan yang dihasilkan pun semakin meningkat serta diiringi dengan bertambahnya jumlah pengangguran terdidik yang ada.

Jika keadaan ini tidak diatasi, meningkatnya pengangguran terdidik akan menimbulkan dampak ekonomis terhadap daerah di sekitarnya. Dibandingkan dengan pengangguran tidak terdidik, pengangguran terdidik memiliki dampak ekonomis yang lebih besar. Hal ini disebabkan pengangguran terdidik dianggap sebagai rate of return yang hilang dari beberapa investasi yang telah diberikan penduduk ketika mengenyam pendidikan. Oleh karena itu, perlu dilakukan penelitian untuk mengetahui penyebab pengangguran lulusan SMA di Provinsi Sumatera Utara pada tahun 2019.

Penelitian terkait pengangguran terdidik sebelumnya pernah dilakukan oleh Aryanti, et al. (2014), hasil penelitiannya mengungkapkan variabel status dalam keluarga, jenis kelamin, umur, status perkawinan, pengalaman kerja, dan wilayah tempat tinggal memengaruhi peluang angkatan kerja terdidik untuk menjadi pengangguran.

Pada penelitian ini, tujuan yang ingin dicapai adalah untuk mengetahui gambaran umum, variabelvariabel yang memengaruhi, serta kecenderungan variabel-variabel yang memengaruhi status menganggur lulusan SMA di Sumatera Utara tahun 2019. Variabel bebas yang digunakan berfokus pada faktor individunya yaitu jenis kelamin, umur, wilayah tempat tinggal, status perkawinan, status dalam rumah tangga, dan pengalaman pelatihan kerja. Hasil dari analisis ini diharapkan dapat membantu pemerintah mengambil kebijakan yang terbaik untuk mengurangi jumlah pengangguran terdidik, khususnya pengangguran lulusan SMA.

\section{METODE}

\section{Landasan Teori}

Sekolah Menengah Atas merupakan jenjang pendidikan menengah pada pendidikan formal di Indonesia setelah lulus Sekolah Menegah Pertama (atau sederajat). SMA juga menerapkan penjurusan atau pengkhususan kemampuan seperti SMK. Pengkhususan tersebut dimulai dari kelas 10 yaitu terdiri dari jurusan IPA (Ilmu Pengetahuan Alam), IPS (Ilmu Pengetahuan Sosial), dan Bahasa. Pengkhususan ini merupakan upaya strategis dalam memfasilitasi peserta didik untuk menyalurkan minat, bakat, dan kemampuan yang dimiliki (Nurhayati, 2017). Sehingga peserta didik memiliki peluang untuk berhasil di masa depan. Lulusan Sekolah Menengah Atas sudah dapat dikategorikan ke dalam angkatan kerja.

Menurut Badan Pusat Statistik, pengangguran terdidik merupakan angkatan kerja yang berpendidikan minimal SMA atau seseorang yang memiliki tingkat pendidikan SMA ke atas yang sedang mencari pekerjaan, mempersiapkan suatu usaha, putus asa karena tidak merasa mampu, atau sudah mempunyai pekerjaan namun belum mulai bekerja. Secara umum, pengangguran terdidik selalu berkaitan dengan masalah pendidikan di negara berkembang, seperti masalah kualitas pendidikan, kesiapan tenaga kerja terdidik, fasilitas serta pandangan masyarakat.

Dari tahun ke tahun jumlah pengangguran terdidik cenderung meningkat. Kecenderungan ini disebabkan bahwa semakin tinggi tingkat pendidikan akan semakin tinggi pula aspirasi untuk mendapatkan kedudukan atau kesempatan kerja yang lebih sesuai (Jaya, 2016). Menurut Tobing (1994) dalam Cahyani (2014), beberapa penyebab meningkatnya pengangguran terdidik yaitu karakteristik lulusan yang baru memasuki dunia kerja tidak sesuai dengan kesempatan kerja yang tersedia, semakin terdidik seseorang maka semakin besar harapannya pada jenis pekerjaan yang nyaman sehingga angkatan kerja terdidik akan lebih memilih untuk menganggur daripada mendapatkan pekerjaan yang tidak sesuai, terbatasnya daya serap tenaga kerja pada sektor formal, dan belum efisiennya peranan dari pasar tenaga kerja.

\section{Cakupan Penelitian}

Unit analisis yang digunakan dalam penelitian ini adalah penduduk yang termasuk angkatan kerja berumur 15 tahun ke atas dengan pendidikan terakhir SMA di Provinsi Sumatera Utara tahun 2019. Data yang digunakan merupakan data sekunder yang diperoleh dari Badan Pusat Statistik hasil Survei Angkatan Kerja 
Nasional bulan Agustus 2019. Variabel terikat yang digunakan adalah status menganggur lulusan SMA yang dibagi menjadi dua kategori yaitu menganggur dan bekerja, sedangkan variabel bebas yang digunakan antara lain jenis kelamin, umur, wilayah tempat tinggal, pelatihan kerja, status perkawinan, dan status dalam rumah tangga.

\section{Metode Analisis}

Metode analisis yang digunakan dalam penelitian ini adalah analisis deskriptif dan analisis inferensia. Analisis deskriptif digunakan untuk menggambarkan secara umum pengangguran lulusan SMA di Provinsi Sumatera Utara tahun 2019 serta karakteristiknya berdasarkan variabel bebas menggunakan tabel dan grafik. Sedangkan analisis inferensia digunakan untuk mengetahui variabel-variabel bebas yang memengaruhi status menganggur lulusan SMA di Provinsi Sumatera Utara tahun 2019 dan menganalisis besarnya kecenderungan dari variabel-variabel tersebut. Metode analisis inferensia yang digunakan adalah regresi logistik biner, karena variabel terikat yang digunakan bersifat biner atau dikotomi. Variabel terikat yang berupa variabel dikotomi ini memiliki dua kemungkinan yang dapat dinyatakan dengan kejadian "sukses" yaitu y=1 dan "gagal" yaitu $\mathrm{y}=0$ (Hosmer and Lemeshow, 2013). Berikut ini tahapan pengujian yang dilakukan yaitu:

1. Pengujian signifikansi parameter secara simultan menggunakan uji likelihood ratio.

$H_{0}: \beta_{1}=\beta_{2}=\ldots=\beta_{6}=0$ (tidak terdapat pengaruh dari variabel bebas terhadap status menganggur lulusan SMA)

$H_{1}$ : Minimal terdapat satu $\beta_{\mathrm{k}} \neq 0$ dengan $\mathrm{k}=1,2,3,4,5$, dan 6 (minimal terdapat satu variabel bebas yang berpengaruh terhadap status menganggur lulusan SMA)

Statistik uji yang digunakan yaitu:

$G=-2 \ln \frac{l_{0}}{l_{1}} \sim \chi_{(6)}^{2}$

Keterangan:

$l_{0}=$ nilai likelihood tanpa variabel bebas

$l_{1}=$ nilai likelihood dengan variabel bebas

Pengambilan keputusan:

Tolak H0 jika G $>\chi_{(0,05 ; 6)}^{2}$ atau $p$-value $<0,05$. Ini artinya dengan taraf signifikansi sebesar 5 persen dapat disimpulkan terdapat minimal satu variabel bebas yang berpengaruh terhadap status menganggur lulusan SMA di Provinsi Sumatera Utara tahun 2019.

2. Pengujian signifikansi parameter secara parsial menggunakan uji Wald.

$H_{0}: \beta_{k}=0$, dengan $\mathrm{k}=1,2,3,4,5$, dan 6 (tidak terdapat pengaruh variabel bebas ke-k terhadap status menganggur lulusan SMA)

$H_{1}: \beta_{k} \neq 0$, dengan $\mathrm{k}=1,2,3,4,5$, dan 6 (terdapat pengaruh variabel bebas ke-k terhadap status menganggur lulusan SMA)

Statistik uji yang digunakan yaitu:

$W_{k}^{2}=\left(\frac{\widehat{\beta}_{k}}{\operatorname{se}\left(\widehat{\beta}_{k}\right)}\right)^{2} \sim \chi_{(1)}^{2}$

Keterangan:

$\hat{\beta}_{k} \quad=$ penduga parameter $\beta_{k}$

$\operatorname{Se}\left(\hat{\beta}_{k}\right)=$ standard error penduga $\beta_{k}$

Pengambilan keputusan:

Tolak H0 jika $\mathrm{W}_{\mathrm{k}}^{2}>\chi_{(0,05 ; 1)}^{2}$ atau $p$-value $<0,05$. Artinya dengan taraf signifikansi sebesar 5 persen dapat disimpulkan variabel bebas ke-k berpengaruh terhadap status menganggur lulusan SMA di Provinsi Sumatera Utara tahun 2019.

3. Pengujian kesesuaian model (Goodness of Fit) menggunakan metode Hosmer-Lemeshow Goodness of Fit Test.

$H_{0}$ : Model sesuai

$H_{1}$ : Model tidak sesuai

Statistik uji yang digunakan yaitu: 


$$
\hat{C}=\sum_{k=1}^{g} \frac{\left(o_{k}-n_{k}^{\prime} \bar{\pi}_{k}\right)^{2}}{n_{k}^{\prime} \bar{\pi}_{k}\left(1-\bar{\pi}_{k}\right)} \sim \chi_{(6)}^{2}
$$

Keterangan:

$n_{k}^{\prime}=$ jumlah total subjek pada kelompok ke-k

$\bar{\pi}_{k}=$ rata-rata dari estimasi probabilitas, $\sum_{j=1}^{C_{k}} \frac{m_{j} \hat{\pi}_{j}}{n_{k}^{\prime}}$

$O_{k}=$ jumlah nilai variabel terikat pada kelompok ke-k, $\sum_{j=1}^{C_{k}} y_{j}$

$C_{k}=$ banyaknya kombinasi variabel penjelas pada kelompok ke-k

$m_{j}=$ jumlah subjek dengan $C_{k}$ kombinasi variabel bebas

Pengambilan keputusan:

Pada uji kesesuaian model, keputusan yang diharapkan adalah gagal tolak H0. Gagal tolak H0 jika $\hat{\mathrm{C}} \leq$ $\chi_{(0,05 ; 6)}^{2}$ atau $p$-value $\geq 0,05$ yang artinya dengan taraf signifikansi sebesar 5 persen dapat disimpulkan model yang terbentuk sudah sesuai.

4. Tabel klasifikasi yang berguna untuk mengklasifikasikan secara benar seseorang lulusan SMA yang menganggur (sensitivity) dan lulusan SMA yang bekerja (specificity). Dalam menentukan nilai sensitivity dan specificity digunakan nilai cutpoint (c) optimal yang didapat dari kurva ROC.

5. Odds ratio yang digunakan untuk melihat kecenderungan angkatan kerja lulusan SMA untuk menganggur ketika variabel-variabel bebas memiliki nilai tertentu.

Pengkategorian variabel yang digunakan pada penelitian ini yaitu:

Tabel 1. Pengkategorian variabel.

\begin{tabular}{ccc}
\hline Variabel & Nama Variabel & Kategori (Dummy Variable) \\
\hline Y & Status Menganggur Lulusan & Bekerja $(0)^{*}$ \\
& SMA & Menganggur $(1)$ \\
D1 & Jenis Kelamin & Perempakian $(1)$ \\
& & $25+$ Tahun $(0)^{*}$ \\
D2 & Umur & $15-24$ Tahun $(1)$ \\
& & Perdesaan $(0)^{*}$ \\
D3 & Perkotaan $(1)$ \\
D4 & Pelatihan Kerja & Pernah $(0)^{*}$ \\
D5 & & Tidak Pernah $(1)$ \\
& Status Perkawinan & Pernah Kawin $(0)^{*}$ \\
D6 & & Belum Kawin $(1)$ \\
& Status Dalam Rumah Tangga & KRT $(0)^{*}$ \\
\end{tabular}

Keterangan: *Kategori referensi

Model yang diajukan adalah sebagai berikut:

$\hat{g}(D)=\hat{\beta}_{0}+\hat{\beta}_{1} D_{1}+\hat{\beta}_{2} D_{2}+\hat{\beta}_{3} D_{3}+\hat{\beta}_{4} D_{4}+\hat{\beta}_{5} D_{5}+\hat{\beta}_{6} D_{6}$ dimana:

$\hat{g}(D)=$ status menganggur lulusan SMA di Provinsi Sumatera Utara

$D_{1} \quad=$ jenis kelamin

$D_{2} \quad=$ umur

$D_{3} \quad$ = wilayah tempat tinggal

$D_{4} \quad$ = pelatihan kerja

$D_{5} \quad=$ status perkawinan

$D_{6} \quad$ = status dalam rumah tangga

\section{HASIL DAN PEMBAHASAN}

Gambaran Umum Status Menganggur Lulusan SMA di Sumatera Utara Tahun 2019 dan VariabelVariabel yang Diduga Memengaruhinya 
Berdasarkan hasil pengolahan data Sakernas Sumatera Utara Agustus 2019, lulusan SMA yang termasuk angkatan kerja adalah sebanyak 8.084 sampel. Jika pengolahan data diberikan penimbang maka lulusan SMA yang termasuk angkatan kerja sebanyak 1.799.203 jiwa. Dari data tersebut, angkatan kerja lulusan SMA di Sumatera Utara didominasi oleh penduduk yang berstatus bekerja yaitu sebesar 92,60 persen, sedangkan penduduk yang berstatus menganggur sebesar 7,40 persen.

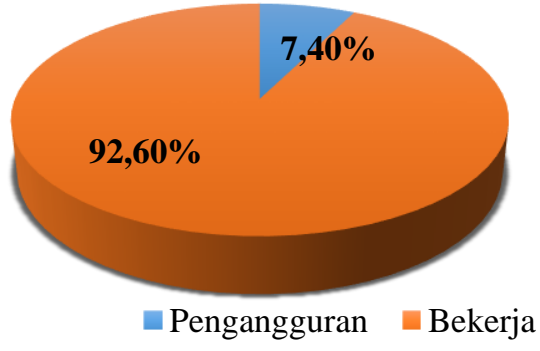

Sumber: Badan Pusat Statistik

Gambar 3. Persentase angkatan kerja lulusan SMA berdasarkan status menganggur

Berdasarkan status menganggur, laki-laki memiliki persentase yang lebih besar dibandingkan dengan perempuan. Laki-laki lulusan SMA yang berstatus menganggur di Sumatera Utara sebesar 7,50 persen. Untuk perempuan lulusan SMA yang berstatus menganggur sebesar 7,30 persen. Pada tabel 2, dapat dilihat bahwa angkatan kerja lulusan SMA yang berstatus menganggur didominasi oleh penduduk berumur muda (15-24 tahun) yaitu sebesar 20,10 persen, sedangkan penduduk berumur dewasa ( 25 tahun ke atas) yang berstatus menganggur sebesar 3,10 persen.

Berdasarkan wilayah tempat tinggal diketahui bahwa persentase angkatan kerja lulusan SMA yang termasuk pengangguran lebih banyak berada di wilayah perkotaan. Persentase angkatan kerja lulusan SMA yang berstatus menganggur di wilayah perkotaan adalah sebesar 8,60 persen. Sedangkan untuk angkatan kerja lulusan SMA yang menganggur di wilayah perdesaan hanya sebesar 5,60 persen. Persentase pengangguran lulusan SMA yang pernah mengikuti pelatihan kerja lebih besar dibandingkan dengan yang tidak pernah mengikuti pelatihan kerja. Dari yang pernah mengikuti pelatihan sebesar 8,30 persen menganggur, sedangkan dari yang belum pernah mengikuti pelatihan sebesar 7,40 persen menganggur.

Jika dilihat dari status perkawinan, persentase pengangguran lulusan SMA yang berstatus belum kawin lebih besar dibandingkan dengan yang berstatus pernah kawin. Persentase mereka yang menjadi pengangguran berstatus belum kawin sebesar 18,40 persen, sedangkan yang berstatus pernah kawin hanya sebesar 2,00 persen. Tabel 2 menunjukkan bahwa pada angkatan kerja lulusan SMA yang berstatus sebagai kepala rumah tangga, persentase yang menganggur sebesar 1,80 persen. Persentase tersebut lebih kecil apabila dibandingkan dengan persentase pengangguran lulusan SMA yang berstatus bukan sebagai kepala rumah tangga, yaitu sebesar 11,10 persen

Tabel 2. Persentase angkatan kerja lulusan SMA berdasarkan status menganggur, jenis kelamin, umur, wilayah tempat tinggal, pelatihan kerja, status perkawinan, dan status dalam rumah tangga.

\begin{tabular}{cccc}
\hline \multirow{2}{*}{ Nama Variabel } & Kategori & \multicolumn{2}{c}{ Status Menganggur Lulusan SMA (\%) } \\
\cline { 2 - 4 } & Laki-Laki & Menganggur & Bekerja \\
\hline \multirow{2}{*}{ Jenis Kelamin } & Perempuan & 7,50 & 92,50 \\
& 15-24 Tahun & 20,10 & 92,70 \\
Umur & 25+ Tahun & 3,10 & 79,90 \\
& Perkotaan & 8,60 & 96,90 \\
Wilayah Tempat Tinggal & Perdesaan & 5,60 & 91,40 \\
& Pernah & 8,30 & 94,40 \\
Pelatihan Kerja & Tidak Pernah & 7,40 & 91,70 \\
\multirow{2}{*}{ Status Perkawinan } & Belum Kawin & 18,40 & 92,60 \\
\multirow{2}{*}{ Status Dalam Rumah } & Pernah Kawin & 2,00 & 81,60 \\
Tangga & KRT & 1,80 & 98,00 \\
& Buka KRT & 11,10 & 98,20 \\
& &
\end{tabular}

Sumber: Badan Pusat Statistik (diolah) 


\section{Variabel yang Memengaruhi Status Menganggur Lulusan SMA di Sumatera Utara Tahun 2019}

Persamaan regresi logistik biner yang terbentuk berdasarkan hasil pengujian yaitu:

$$
\hat{g}(D)=-4,582-0,158 D_{1}+0,929 D_{2}^{*}+0,690 D_{3}^{*}-0,160 D_{4}+1,558 D_{5}^{*}+0,612 D_{6}^{*} .
$$

dimana:

$\hat{g}(D)=$ status menganggur lulusan SMA di Provinsi Sumatera Utara

$D_{1} \quad=$ jenis kelamin

$D_{2} \quad$ umur

$D_{3} \quad$ = wilayah tempat tinggal

$D_{4} \quad=$ pelatihan kerja

$D_{5} \quad$ = status perkawinan

$D_{6} \quad=$ status dalam rumah tangga

* $\quad=$ signifikan pada alfa 5 persen

1. Uji simultan

Berdasarkan hasil dari uji likelihood ratio diperoleh nilai statistik uji $\mathrm{G}$ sebesar 748,210 dengan $p$-value 0,000 . Nilai $p$-value lebih kecil dari alfa 0,05 sehingga keputusan yang diperoleh adalah tolak H0. Dengan demikian, dapat disimpulkan bahwa pada taraf signifikansi 5 persen terdapat minimal satu variabel bebas yang berpengaruh secara signifikan terhadap status menganggur lulusan SMA di Provinsi Sumatera Utara tahun 2019.

Tabel 3. Hasil uji simultan.

\begin{tabular}{cccc}
\hline & Chi-Square & $d f$ & $P$-value \\
\hline Omnibus Test & 748,210 & 6 & 0,000 \\
\hline Sumber: Badan Pusat Statistik (diolah) & & &
\end{tabular}

Sumber: Badan Pusat Statistik (diolah)

\section{Uji parsial}

Hasil dari uji Wald digunakan untuk mengetahui variabel bebas mana saja yang secara signifikan memengaruhi variabel terikat. Variabel bebas dikatakan berpengaruh signifikan terhadap status menganggur lulusan SMA di Provinsi Sumatera Utara tahun 2019 apabila memiliki nilai statistik uji Wald lebih besar dari $\chi_{(0,05,1)}^{2}$ yaitu 3,84 atau nilai $p$-value lebih kecil dari alfa 0,05. Berdasarkan hasil pada Tabel 4, diketahui bahwa variabel umur, wilayah tempat tinggal, status perkawinan, dan status dalam rumah tangga memiliki pengaruh yang signifikan terhadap status menganggur lulusan SMA.

Tabel 4. Hasil uji parsial.

\begin{tabular}{ccccccc}
\hline Variabel & $\hat{\beta}$ & SE & Wald & $d f$ & $P$-value & $\operatorname{Exp}(\hat{\beta})$ \\
\hline Constant & $-4,582$ & 0,234 & 381,869 & 1 & 0,000 & 0,010 \\
Jenis Kelamin (Perempuan) & $-0,158$ & 0,106 & 2,207 & 1 & 0,137 & 0,854 \\
Umur (15-24 Tahun) & 0,929 & 0,135 & 47,398 & 1 & 0,000 & 2,533 \\
Wilayah Tempat Tinggal (Perkotaan) & 0,690 & 0,103 & 44,935 & 1 & 0,000 & 1,993 \\
Pelatihan Kerja (Tidak Pernah) & $-0,160$ & 0,192 & 0,690 & 1 & 0,406 & 0,853 \\
Status Perkawinan (Belum Kawin) & 1,558 & 0,175 & 78,801 & 1 & 0,000 & 4,748 \\
Status Dalam Rumah Tangga (Bukan KRT) & 0,612 & 0,193 & 10,063 & 1 & 0,002 & 1,845 \\
\hline
\end{tabular}

Sumber: Badan Pusat Statistik (diolah)

\section{Uji kesesuaian model}

Berdasarkan hasil pengujian menggunakan Hosmer-Lemeshow Goodness of Fit didapatkan nilai statistik uji sebesar 8,578 dan p-value 0,199. Nilai $p$-value lebih besar dari alfa 0,05 sehingga tidak terdapat cukup bukti untuk menolak $\mathrm{H}_{0}$. Dengan demikian, dapat disimpulkan bahwa pada taraf signifikansi 5 persen, model yang terbentuk sudah sesuai untuk menjelaskan data yang digunakan dalam penelitian. 
Tabel 5. Hasil uji kesesuaian model.

\begin{tabular}{cccc}
\hline & Chi-Square & $d f$ & $P$-value \\
\hline Hosmer and Lemeshow Test & 8,578 & 6 & 0,199 \\
\hline
\end{tabular}

Sumber: Badan Pusat Statistik (diolah)

4. Tabel klasifikasi

Hasil tabel klasifikasi pada Tabel 6 dengan menggunakan nilai cutpoint optimal sebesar 0,048 menunjukkan nilai overall percentage yang terbentuk adalah 75,50 persen. Sehingga dapat disimpulkan model yang terbentuk dapat memprediksi status menganggur lulusan SMA di Sumatera Utara tahun 2019 secara tepat sebesar 75,50 persen. Selain itu, nilai sensitivity sebesar 81,20 persen yang menjelaskan bahwa ketepatan model dalam mengklasifikasikan jumlah observasi ke dalam jumlah prediksi untuk kategori menganggur adalah 81,20 persen. Sedangkan nilai specificity sebesar 75,10 persen menjelaskan bahwa ketepatan model dalam mengklasifikasikan jumlah observasi ke dalam jumlah prediksi untuk kategori bekerja adalah 75,10 persen.

Tabel 6. Hasil tabel klasifikasi.

\begin{tabular}{|c|c|c|c|c|}
\hline \multirow{2}{*}{\multicolumn{2}{|c|}{ Observasi }} & \multicolumn{2}{|c|}{ Prediksi } & \multirow{3}{*}{ Percentage Correct } \\
\hline & & \multicolumn{2}{|c|}{ Status Menganggur Lulusan SMA } & \\
\hline & & Bekerja & Menganggur & \\
\hline \multirow{2}{*}{$\begin{array}{l}\text { Status Menganggur } \\
\text { Lulusan SMA }\end{array}$} & Bekerja & 5.694 & 1.886 & $75,10 \%$ \\
\hline & Menganggur & 95 & 409 & $81,20 \%$ \\
\hline \multicolumn{2}{|c|}{ Overall Percentage } & & & $75,50 \%$ \\
\hline
\end{tabular}

Sumber: Badan Pusat Statistik (diolah)

\section{Kecenderungan Variabel-Variabel yang Memengaruhi Status Menganggur Lulusan SMA di Sumatera Utara Tahun 2019}

Berikut ini kecenderungan masing-masing variabel bebas yang memengaruhi status menganggur lulusan SMA di Provinsi Sumatera Utara tahun 2019 yang dilihat dari nilai odds ratio:

1. Pengaruh jenis kelamin terhadap status menganggur lulusan SMA.

Variabel jenis kelamin tidak signifikan memengaruhi angkatan kerja lulusan SMA di Provinsi Sumatera Utara tahun 2019 untuk menjadi pengangguran. Hartoko (2018) mengatakan jika tenaga kerja laki-laki mengalami masa mencari kerja yang lebih panjang daripada tenaga kerja perempuan. Masa pencarian kerja yang lebih singkat bagi perempuan menunjukkan bahwa perempuan lebih mudah untuk terserap di dunia kerja walaupun harus bekerja di sektor informal. Hal ini menjadi bukti jika perempuan dapat berpartisipasi aktif di dunia kerja seperti laki-laki.

2. Pengaruh umur terhadap status menganggur lulusan SMA.

Variabel umur signifikan memengaruhi angkatan kerja lulusan SMA menjadi pengangguran di Provinsi Sumatera Utara tahun 2019. Nilai odds ratio dari variabel umur adalah sebesar 2,533. Artinya angkatan kerja lulusan SMA yang berumur muda yaitu 15-24 tahun memiliki kecenderungan untuk menganggur sebesar 2,533 kali dibandingkan dengan angkatan kerja lulusan SMA yang berumur dewasa atau 25 tahun ke atas. Kondisi tersebut juga sesuai karena pengangguran terdidik didominasi penduduk usia muda yang menunggu mendapatkan pekerjaan yang pas (Pratomo, 2017). Angkatan kerja yang berumur muda pada umumnya belum memiliki tanggung jawab yang besar untuk menafkahi keluarga, sehingga akan memakan waktu yang lama untuk memilih pekerjaan yang sesuai dengan keinginan mereka. Sedangkan angkatan kerja yang berumur dewasa atau 25 tahun ke atas cenderung memandang bekerja sebagai sebuah keharusan karena sudah memiliki tanggung jawab untuk memberi nafkah keluarganya.

3. Pengaruh wilayah tempat tinggal terhadap status menganggur lulusan SMA.

Wilayah tempat tinggal signifikan memengaruhi angkatan kerja lulusan SMA untuk menjadi pengangguran di Provinsi Sumatera Utara tahun 2019. Angkatan kerja lulusan SMA yang tinggal di wilayah perkotaan memiliki kecenderungan untuk menjadi pengangguran sebesar 1,993 kali dibandingkan dengan yang tinggal di wilayah perdesaan. Banyak penduduk yang ingin mendapatkan pekerjaan yang layak menyebabkan mereka mencari pekerjaan di perkotaan, baik pada sektor formal maupun sektor informal. Kegiatan migrasi dari perdesaan ke perkotaan ini dapat meningkatkan pertumbuhan pencari kerja di perkotaan terutama pencari kerja berusia muda (Todaro dan Smith, 2012). Tingginya jumlah pencari kerja dibandingkan ketersediaan lapangan pekerjaan akan mengakibatkan jumlah pengangguran di perkotaan terus meningkat. 
4. Pengaruh pelatihan kerja terhadap status menganggur lulusan SMA.

Variabel pelatihan kerja tidak signifikan memengaruhi angkatan kerja lulusan SMA untuk menganggur di Provinsi Sumatera Utara tahun 2019. Hal ini membuktikan bahwa program pelatihan yang dilaksanakan oleh pemerintah tidak berdampak besar pada mereka untuk mendapatkan pekerjaan. Selain itu adanya ketidaksesuaian keahlian yang didapat dari pelatihan dengan permintaan lapangan kerja. Berdasarkan persentase angkatan kerja lulusan SMA yang menganggur dan bekerja pada Tabel 2 tidak menunjukkan perbedaan yang besar antara mereka yang pernah mengikuti pelatihan kerja dengan yang tidak pernah mengikuti pelatihan keja.

5. Pengaruh status perkawinan terhadap status menganggur lulusan SMA.

Variabel status perkawinan signifikan memengaruhi angkatan kerja lulusan SMA untuk menganggur di Provinsi Sumatera Utara tahun 2019. Angkatan kerja lulusan SMA yang berstatus belum kawin memiliki kecenderungan yang besar untuk menjadi pengangguran yaitu 4,748 kali dibandingkan dengan angkatan kerja lulusan SMA yang berstatus kawin, cerai hidup dan cerai mati. Kondisi ini disebabkan karena angkatan kerja yang sedang dalam ikatan perkawinan, cerai hidup atau pun cerai mati memiliki tanggungan keluarga yang besar, baik istri, suami, dan anak. Berbeda dengan angkatan kerja yang belum menikah, mereka belum memiliki banyak tanggungan keluarga dan cenderung hanya bertanggung jawab terhadap kebutuhan dirinya sendiri. Aryanti et al. (2014) juga mengatakan jika status belum kawin biasanya belum memiliki tanggung jawab ekonomi dalam keluarga sehingga masih punya waktu menunggu pekerjaan yang cocok.

6. Pengaruh status dalam rumah tangga terhadap status menganggur lulusan SMA.

Status dalam rumah tangga signifikan memengaruhi angkatan kerja lulusan SMA di Provinsi Sumatera Utara tahun 2019 untuk menjadi pengangguran. Angkatan kerja lulusan SMA yang berstatus bukan sebagai kepala rumah tangga memiliki kecenderungan untuk menjadi pengangguran sebesar 1,845 kali dibandingkan dengan yang berstatus sebagai kepala rumah tangga. Tanggung jawab yang besar terhadap rumah tangganya mengakibatkan angkatan kerja yang berstatus sebagai kepala rumah tangga harus bekerja, baik pada sektor formal maupun informal. Sedangkan mereka yang berstatus bukan kepala rumah tangga tidak mempunyai kewajiban untuk memiliki penghasilan dan menafkahi keluarga. Mereka akan cenderung memilih pekerjaan yang sesuai dan berakibat akan memakan waktu cukup lama untuk menganggur.

\section{KESIMPULAN}

Berdasarkan hasil dan pembahasan yang telah diperoleh, penduduk di Provinsi Sumatera Utara pada tahun 2019 yang termasuk dalam angkatan kerja lulusan SMA yaitu sebanyak 1.799.203 jiwa di mana 7,40 persen berstatus sebagai pengangguran dan 92,60 persen berstatus bekerja. Pengangguran lulusan SMA di Sumatera Utara didominasi oleh laki-laki, berumur muda atau 15-24 tahun, berstatus belum kawin, tinggal di wilayah perkotaan, bukan berstatus sebagai kepala rumah tangga, dan sudah pernah mengikuti pelatihan kerja. Variabel-variabel yang signifikan memengaruhi angkatan kerja lulusan SMA untuk menjadi pengangguran di Provinsi Sumatera Utara tahun 2019 adalah variabel umur, wilayah tempat tinggal, status perkawinan, dan status dalam rumah tangga. Sedangkan variabel pelatihan kerja dan jenis kelamin tidak signifikan memengaruhi lulusan SMA untuk menjadi pengangguran. Angkatan kerja lulusan SMA yang berumur 15-24 tahun, tinggal di wilayah perkotaan, berstatus bukan sebagai kepala rumah tangga dan belum kawin memiliki kecenderungan yang lebih besar untuk menganggur.

\section{DAFTAR PUSTAKA}

Alam, Syamsyul. (2016). Tingkat Pendidikan dan Pengangguran di Indonesia (Telaah Serapan Tenaga Kerja SMA/SMK dan Sarjana). Jurnal Ilmiah Bongaya (Manajemen dan Akuntansi), (14), 250-257.

Aryanti, Fitri, Sunaryanto, Heri, Sunoto. (2014). Analisis Pengangguran Terdidik di Provinsi Bengkulu. Jurnal Ekonomi dan Perencanaan Pembangunan (JEPP), 5(4), 70-79.

Badan Pusat Statistik. (2018). Keadaan Angaktan Kerja di Provinsi Sumatera Utara Agustus 2018. Sumatera Utara: Badan Pusat Statistik.

Badan Pusat Statistik. (2019a). Keadaan Angkatan Kerja di Indonesia Agustus 2019. Jakarta: Badan Pusat Statistik.

Badan Pusat Statistik. (2019b). Keadaan Angkatan Kerja di Provinsi Sumatera Utara Agustus 2019. Sumatera Utara: Badan Pusat Statistik

Badan Pusat Statistik. (2019). Survei Angkatan Kerja Nasional Agustus 2019. Jakarta: Badan Pusat Statistik. Cahyani, Indah Gita. (2014). Analisis Faktor-Faktor yang Memengaruhi Pengangguran Terdidik di Sulawesi Selatan. Disertasi Universitas Hasanuddin. Makassar. $82 \mathrm{hlm}$. 
Hartoko, Yosef. (2018). Pengaruh Pendidikan, Pelatihan, Jenis Kelamin, Umur, Status Perkawinan, dan Daerah Tempat Tinggal Terhadap Lama Mencari Kerja Tenaga Kerja Terdidik di Indonesia. Skripsi Universita Negeri Yogyakarta. Yogyakarta. $113 \mathrm{hlm}$.

Hosmer, David W. and Lemeshow, Stanley. (2013). Applied Logistic Regression Third Edition. New Jersey: John Wiley and Sons.

Jaya, Fitri Pertiwi. (2016). Analisis Determinan Pengangguran Terdidik (Studi Kasus Kecamatan Manggala Kota Makassar). Skripsi Universitas Islam Negeri Alauddin Makassar. Makassar. $115 \mathrm{hlm}$.

Kementerian Pendidikan dan Kebudayaan. (2019). Data Pokok Pendidikan: Data Peserta Didik. Cited in https://dapo.dikdasmen.kemendikbud.go.id/pd. [10 Oktober 2020]

Nurhayati, F. (2017). Aplikasi Klasifikasi Penentuan Jurusan SMA di Madrasah Aliyah Negeri 2 Gresik dengan Metode FK-NN. Gresik: Universitas Muhammadiyah Gresik.

Pratomo, Devanto Shasta. (2017). Fenomena Pengangguran Terdidik di Indonesia. Malang: Universitas Brawijaya.

Tobing, Elwin. (2007). Pengangguran Tenaga Kerja Terdidik. Jakarta: Jurnal Kajian Strategis Gema Nusa.

Todaro, M. P. and Smith, S. C. (2012). Economic Development Eleventh Edition. New York: Pearson.

Umar, Muhammad Agus. (2017). Bonus Demografi Sebagai Peluang dan Tantangan Pengelolaan Sumber Daya Alam di Era Otonomi Daerah. Genta Mulia: Jurnal Ilmiah Pendidikan, 8(2), 90-99. 